\title{
Ammonium Alunite and Basic Aluminum Sulfate: Effect of Precipitant Agent
}

\author{
Adrián Zamorategui Molina ${ }^{1, *}$, Julio del Ángel Soto², Merced Martínez Rosales², \\ Rafael Romero Toledo ${ }^{2}$ \\ ${ }^{1}$ Department of Civil Engineering, University of Guanajuato, Guanajuato, Gto., Mexico \\ ${ }^{2}$ Department of Chemistry, University of Guanajuato, Guanajuato, Gto., Mexico
}

\section{Email address:}

zamorategui@ugto.mx (A. Z. Molina)

\section{To cite this article:}

Adrián Zamorategui Molina, Julio del Ángel Soto, Merced Martínez Rosale, Rafael Romero Toledo. Ammonium Alunite and Basic Aluminum Sulfate: Effect of Precipitant Agent. International Journal of Materials Science and Applications. Vol. 4, No. 2, 2015 , pp. 96-100. doi: $10.11648 /$ j.ijmsa.20150402.14

\begin{abstract}
Ammonium bisulfite as a precipitating agent was used to synthesize basic aluminum sulfate (BAS) by homogeneous precipitation. Aluminum sulfate in aqueous solution was used as the raw material. High concentration of the precipitant agent promotes the formation of ammonium alunite, which was confirmed by XRD, TG/DTG and FTIR analysis. The ammonium alunite has less sulfate ions and more water than the BAS, and so, the ammonium alunite heat treated up to $1200^{\circ} \mathrm{C}$ produces 28 weight percent of $\mathrm{Al}_{2} \mathrm{O}_{3}$. In comparison the BAS generates 48 weight percent of $\mathrm{Al}_{2} \mathrm{O}_{3}$ as a final product. Homogeneous precipitation promotes the formation of amorphous spherical particles of basic aluminum sulfate and lamellar crystalline particles of ammonium alunite which were observed by field emission microscopy (FEM).
\end{abstract}

Keywords: Ammonium Bisulfite, Ammonium Alunite, Basic Aluminum Sulfate, Homogeneous Precipitation

\section{Introduction}

Basic aluminum sulfate (BAS) has been used widely as precursor material for preparation of pseudoboehmite, activated alumina $\left(\gamma-\mathrm{Al}_{2} \mathrm{O}_{3}\right)$, catalysts and special ceramic products [1-3]. Several methods are available for synthesis of BAS (sol-gel, microwave, homogeneous precipitation, hydrothermal synthesis, etc.). Sugimoto et al., discussed the standard formation process of monodisperse microcrystal of BAS by the sol gel method under acidic condition at $100^{\circ} \mathrm{C}$ for 3 days. Simpson et al., published the results of the first study on precipitation of BAS at room temperature using urease as a catalyst for the decomposition of urea [4-6].

The synthesis of BAS by homogeneous precipitation can be made by heating a mixture of aqueous solutions of an economical precipitant agent (urea, urea-ureasa, $\mathrm{Na}_{2} \mathrm{CO}_{3}$, ammonium carbonate, formamide, etc.) and aluminum salt up to its approximate boiling temperature. This precipitation process is carried out in a short time and appears to be industrially advantageous $[7,8]$. The behavior of the urea as a precipitating agent of the aluminum salts in aqueous solution has been investigated. The $\mathrm{pH}$ of the solution can be controlled with the ammonia produced via the thermal decomposition of the urea in the temperature range of $90^{\circ}$ $100^{\circ} \mathrm{C}$ for 3 hours. However, an excess of urea promotes the formation of the oxide-hydroxides (boehmite) by increasing the $\mathrm{pH}$ above $9[9,10]$.

Ammonium bisulfite as a precipitant agent has been used to synthesis BAS by homogeneous precipitation. The thermal decomposition of the precipitant agent initiates at around $80^{\circ} \mathrm{C}$ and the precipitations of the solid BAS occur by increasing of the temperature up to $85^{\circ} \mathrm{C}$, which is maintained for 30 minutes with constant agitation $[11,12]$. In comparison with other precipitant agents, ammonium alunite is formed when ammonium bisulfite is used in excess.

Ammonium alunite $\left(\mathrm{NH}_{4} \mathrm{Al}_{3}\left(\mathrm{SO}_{4}\right)_{2}(\mathrm{OH})_{6}\right)$ is a member of the alunite group of minerals which form part of the alunite super group. As it has been reported, the general chemical formula is represented by $\mathrm{DG}_{3}\left(\mathrm{TO}_{4}\right)_{2}\left(\mathrm{OH}, \mathrm{H}_{2} \mathrm{O}\right)_{6}$ where the $\mathrm{D}$ can be a monovalent $\left(\mathrm{Na}^{+}, \mathrm{K}^{+}, \mathrm{NH} 4^{+}\right)$, divalent $\left(\mathrm{Ca}^{2+}, \mathrm{Ba}^{2+}\right.$, $\left.\mathrm{Sr}^{2+}, \mathrm{Pb}^{2+}\right)$ or trivalent cation $\left(\mathrm{Bi}^{3+}\right), \mathrm{G}$ is a trivalent cation $\left(\mathrm{Al}^{3+}\right.$ or $\left.\mathrm{Fe}^{3+}\right)$ and $\mathrm{T}$ is a hexavalent or pentavalent cation: $\mathrm{S}^{6+}$, $\mathrm{As}^{5+}$ or $\mathrm{P}^{5+}[13,14]$. The alunites can be used to remove heavy metals, being important materials from an 
environmental point of view. The natural alunites are formed in acid soils where the $\mathrm{pH}$ is below 3 , and whereas synthetic alunite has been synthesized in autoclave vessels maintained at around $150^{\circ} \mathrm{C}$ for two days.

Homogeneous precipitation allows controlling physical properties, crystal structure, morphology, specific surface area, porous volume and particle size of the final product. These properties depend on the type of precipitating agent, ratio $\mathrm{H}_{2} \mathrm{O} / \mathrm{Al}_{2}\left(\mathrm{SO}_{4}\right)_{3}, \mathrm{pH}$, temperature and aging time [15]. Ammonium bisulfite is an excellent precipitating agent to synthesize porous materials $[11,12,16]$, however; the authors were not able to find any report of its use in synthesizing ammonium alunite. The objective of this study is to synthesize ammonium alunite and basic aluminum sulfate varying the ratio of the ammonium bisulfite and aluminum sulfate.

\section{Experimental Procedure}

Ammonium alunite and basic aluminum sulfate were synthesized by homogeneous precipitation using a mixture of aqueous solutions of aluminum sulfate $\left(\mathrm{Al}_{2}\left(\mathrm{SO}_{4}\right)_{3} \cdot 18 \mathrm{H}_{2} \mathrm{O}\right)$ and the precipitating agent. The aluminum sulfate solution was prepared dissolving technical grade aluminum salt in distilled water and filtered to remove insoluble material. The final concentration of the solutions was adjusted to $0.6 \mathrm{M}$ with distilled water. The ammonium bisulfate $\left(\mathrm{NH}_{4} \mathrm{HSO}_{3}\right)$ solution $(\rho=1.3 \mathrm{~g} / \mathrm{mL})$ used as the precipitant agent in the homogeneous precipitation was prepared in the laboratory by reacting gases (ammonia and sulfur dioxide) in distilled water

Samples were prepared mixing aluminum sulfate/ammonium bisulfite solutions at a volume ratio: $3.8 / 1$, 2.9/1, 2/1 and 1.4/1 (BAS130, BAS170, BAS250 and BAS350). Then they were heated up to $85^{\circ} \mathrm{C}$ for 30 minutes with constant agitation at $350 \mathrm{rpm}$. So, the ammonium bisulfite solution decomposes into sulfur dioxide and ammonium sulfite at about $80^{\circ} \mathrm{C}$, as shown in the reaction:

$$
2 \mathrm{NH}_{4} \mathrm{HSO}_{3(\mathrm{ac})} \rightarrow\left(\mathrm{NH}_{4}\right)_{2} \mathrm{SO}_{3(\mathrm{ac})}+\mathrm{H}_{2} \mathrm{O}_{(\mathrm{l})}+\mathrm{SO}_{2(\mathrm{~g})}
$$

The ammonium released by thermal decomposition of ammonium bisulfite gradually increases the $\mathrm{pH}$ of the solution to about 4.4 , which promotes the precipitation of the BAS [17] and then, the white precipitate was filtered and washed with hot water. The final product was dried at $110^{\circ} \mathrm{C}$ in an oven for 12 hours. Crystalline phase formation was analyzed by a conventional X-ray diffraction technique using a Siemens D500 Difractometer between $10^{\circ}$ and $80^{\circ}$, with monochromatic $\mathrm{Cu} \mathrm{K \alpha}$ radiation, filter of $\mathrm{Ni}$ at $30 \mathrm{kV}$. Thermal decomposition was conducted in TGA/DTA (TA Instrument: DMA, SDT 2960) in a flowing air atmosphere at a heating rate of $10^{\circ} \mathrm{C} / \mathrm{min}$ from $25^{\circ} \mathrm{C}$ to $1250^{\circ} \mathrm{C}$ using alpha alumina $\left(\alpha-\mathrm{Al}_{2} \mathrm{O}_{3}\right)$ as the reference material; Fourier transform infrared spectroscopy (FTIR) was carried out using the Perkin Elmer (1600 series) in the range of $400 \mathrm{~cm}^{-1}$ to $4000 \mathrm{~cm}^{-1}$ using $\mathrm{KBr}$ pellets. Field emission scanning electron microscopy (FE-SEM) was used to observe the morphology.

\section{Results and Discussion}

\subsection{Effect of the Precipitant Agent on the Final Mass Precipitate}

Figure 1 shows the weight of the obtained dried precipitate against the volumetric ratio of the solutions: aluminum sulfate/ammonium bisulfite.

The weight of the dried sample increases with low ratio. The thermal dissociation of the ammonium bisulfite releases ammonium, water and sulfur dioxide, which in turn react forming ammonium alunite. This result was confirmed by $\mathrm{XRD}$ analysis.

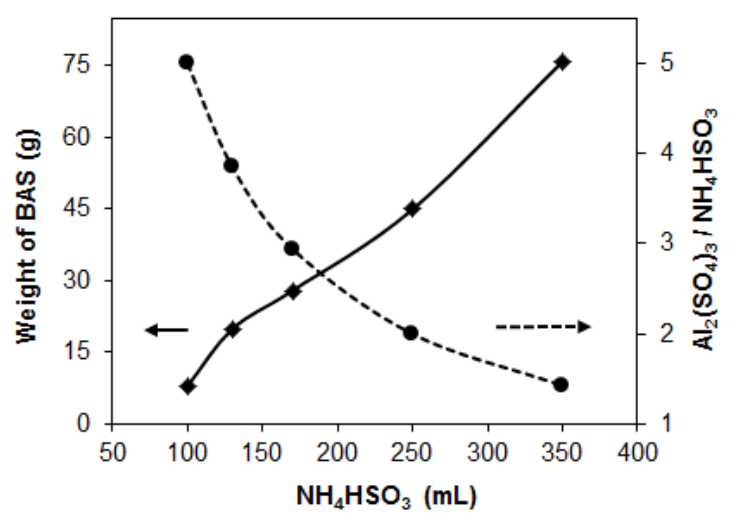

Figure 1. Dried weight of the samples.

\subsection{XRD Diffraction}

X-ray diffraction patterns of the samples are shown in figure 2. As can be seen, BAS130 and BAS170 samples exhibit the small XRD peaks of the amorphous basic aluminum sulfate. However, the BAS250 and BAS350 diffractograms are in good agreement with the standard diffraction pattern of the ammonium alunite which has been reported [13]. This is an effect of the high concentration of the precipitant agent used which promotes the formation of ammonium alunite.

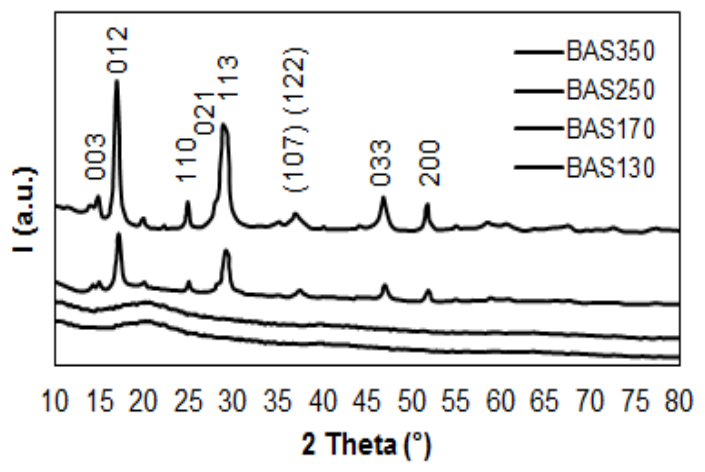

Figure 2. X-ray diffraction patterns of the samples.

\subsection{Thermal Analysis TG/DTG}

Thermal analysis TG/DTG of the samples is shown in figure 3. Basic aluminum sulfates (BAS130 and BAS170) present three weight losses at about 150,400 and $900^{\circ} \mathrm{C}$. 
These, are attributable to the release of physically adsorbed water, thermal dehydroxylation and desulphation process related to the removal of all sulfate ions, respectively. Additionally, the samples BAS250 and BAS350 present two other important weight losses at $270^{\circ} \mathrm{C}$ and $650^{\circ} \mathrm{C}$. As reported, these mass losses correspond principally to the removal of the $\mathrm{NH}_{3}$ gas and $\mathrm{SO}_{2}$ formed by the decomposition of aluminum hydrogen sulfate, respectively $[18,19]$. Finally, the BAS170 sample has more weight percent of $\mathrm{Al}_{2} \mathrm{O}_{3} \quad(48 \%)$ and sulfate ions (22\%), in comparison with the BAS350 which has less mass of $\mathrm{Al}_{2} \mathrm{O}_{3}$ $(28 \%)$ and sulfate ions $(15 \%)$ as shown in figures $3 a-b$.

The TG and DTG curves of the BAS130 and BAS170 confirm the formation of basic aluminum sulfate at a low concentration of the precipitant agent or vice versa. High concentration promotes the formation of ammonium alunite as it was discussed before (Fig. 2).
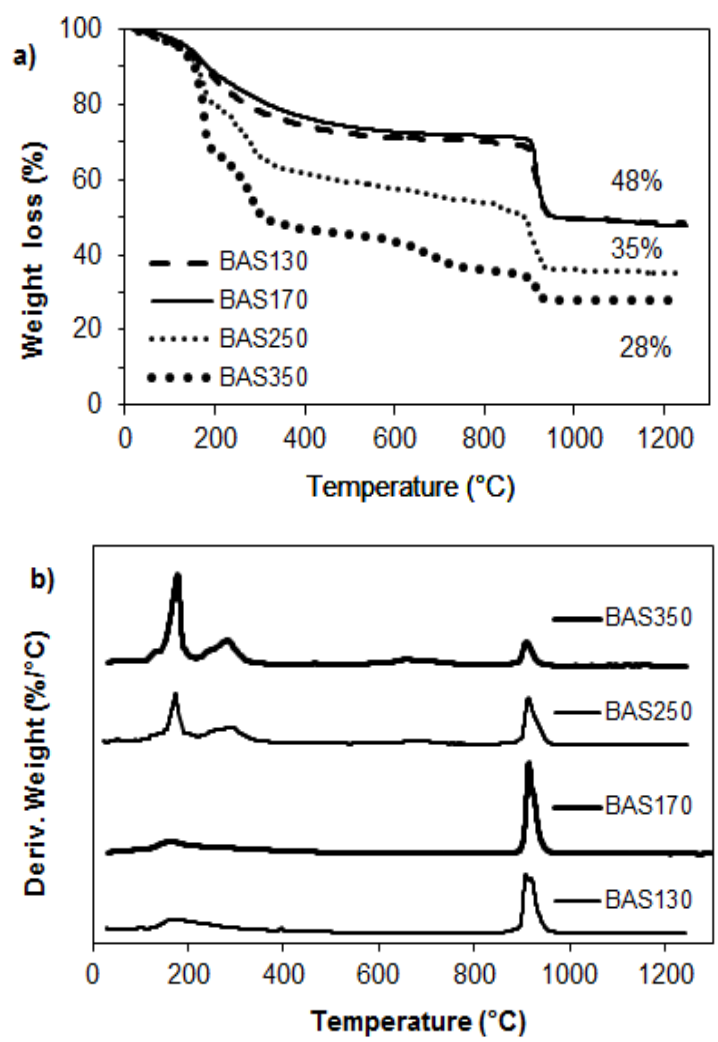

Figure 3. a) TG and b) DTG curves of the basic aluminum sulfate and ammonium alunite.

This fact can be explained for the thermal decomposition of the ammonium bisulfite in ammonium and sulfur dioxide, and so, the excess of these are incorporated in the structure of the final precipitate and this generates the formation of the ammonium alunite (BAS250 and BAS350).

\subsection{FTIR Study}

Figure 4a shows the FTIR spectra of BAS and ammonium alunite. In the spectrums of the BAS130 and BAS170 five absorption bands can be observed, the first at $3445 \mathrm{~cm}^{-1}$ corresponding to the vibration modes $v_{1}$ and $v_{3}$ of the water molecules and bond stretching H-O groups, the second band located at $1635 \mathrm{~cm}^{-1}$ corresponding to the vibration mode $v_{2}$ of the coordination water, the third, fourth and fifth absorptions appear at $1140 \mathrm{~cm}^{-1}, 990 \mathrm{~cm}^{-1}$ and $610 \mathrm{~cm}^{-1}$ corresponding to the vibrations $v_{3}, v_{1}$ and $v_{4}$, respectively of the sulfate ion $\left(\mathrm{SO}_{4}{ }^{2-}\right)[20,21]$. Furthermore, BAS250 and BAS350 (ammonium alunite) spectra present an absorption band at 3650 attributable to the presence of the inter lamellar bond $\mathrm{O}-\mathrm{H}$, three absorption bands $v_{3}$ at $3538,3280,2860 \mathrm{~cm}^{-}$ ${ }^{1}$ (N-H stretch) and one bending vibrational band for $\mathrm{NH}_{4}{ }^{+}$at $1440 \mathrm{~cm}^{-1}$ which is slightly detected in the BAS170. Finally, the absorption at $1250 \mathrm{~cm}^{-1}$ is ascribed to the bending vibration of the hydroxyl groups in the lattice. The infrared spectrums concur with the result obtained by XRD and TG/DTG as discussed before [20-23].
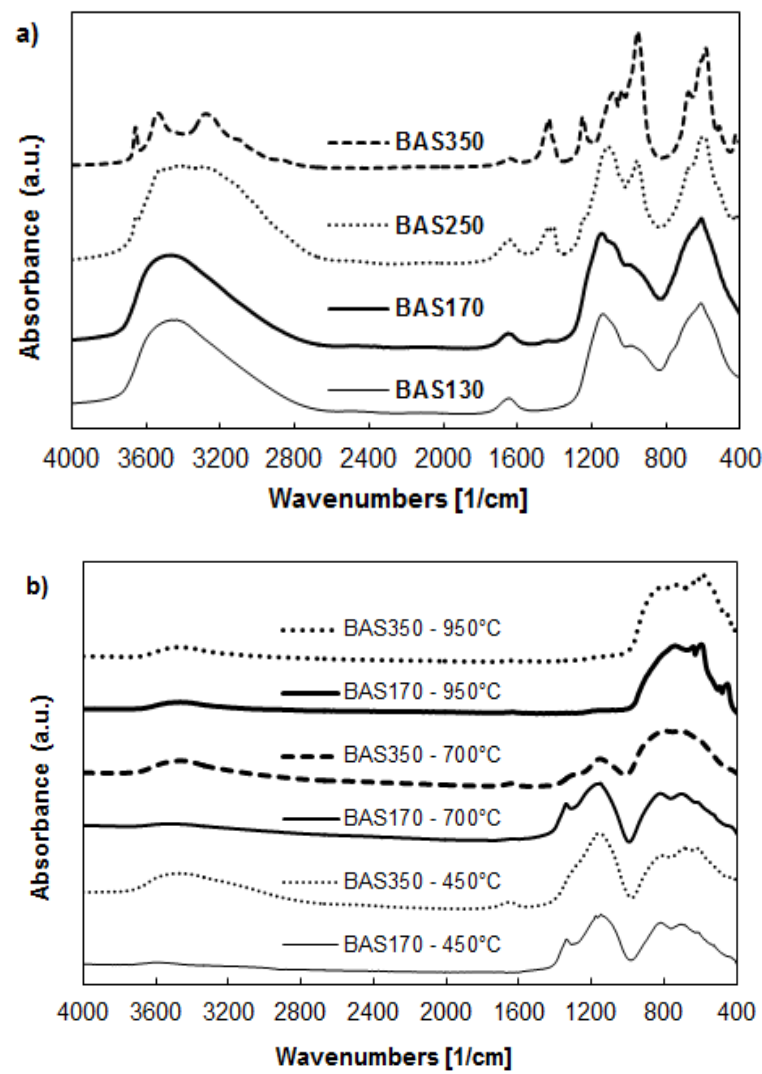

Figure 4. FTIR spectra of the samples: a) dried at $110^{\circ} \mathrm{C}$ and b) $\mathrm{BAS} 170$ and $B A S 350$ heat treated at 450,700 and $950^{\circ} \mathrm{C}$.

Figure 4 b) shows the spectrum of the BAS170 and BAS350 heat treated at 450,700 and $950^{\circ} \mathrm{C}$. As it can be seen, the corresponding absorption bands $(3538,3280,2860$ and $1440 \mathrm{~cm}^{-1}$ ) of the ammonium ion are not observed in any samples at $450^{\circ} \mathrm{C}$ confirming that ammonium gas was released below this temperature. As can be seen, the absorption band at $3520 \mathrm{~cm}^{-1}$ associated with crystal water or $\mathrm{Al}-\mathrm{H}_{2} \mathrm{O}$ and $\mathrm{Al}-\mathrm{OH}$ is wider and higher for the BAS350 in agreement with the result obtained by $\mathrm{TG}$ and discussed before. On the other hand, the sulfate ions are retained and the corresponding absorption bands appeared at $700^{\circ} \mathrm{C}$ and these are not observed in the spectrums of the BAS170 and BAS350 heat treated at $950^{\circ} \mathrm{C}$. Vibrational frequencies below 
$1000 \mathrm{~cm}^{-1}$ represent $\mathrm{Al}-\mathrm{O}$ interaction into the bulk structure. It has been established that $\mathrm{AlO}_{6}$ octahedral and $\mathrm{AlO}_{4}$ tetrahedral present vibrational frequencies in the range 500 $700 \mathrm{~cm}^{-1}$ and $700-900 \mathrm{~cm}^{-1}$ respectively. This confirms the formation of $\gamma-\mathrm{Al}_{2} \mathrm{O}_{3}$ at $950^{\circ} \mathrm{C}$ [24].

\subsection{Particle Size and Morphology}
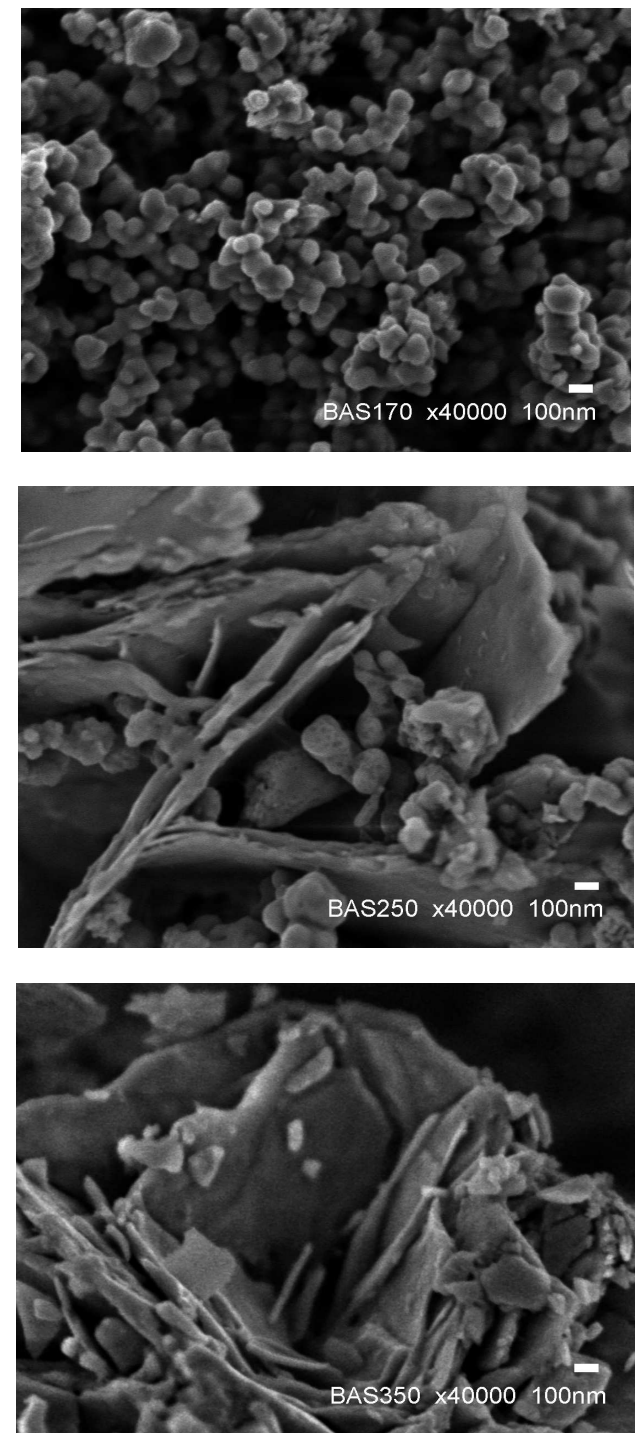

Figure 5. Particle size and morphology of the BAS170, BAS250 and BAS350

Emission scanning electron micrographs are shown in figure 5. Using a ratio of aluminum sulfate/ammonium bisulfate solutions above 3 , the precipitant agent promotes the formation of amorphous basic aluminum sulfate (BAS170) with spherical morphology and particles the size of about $150 \mathrm{~nm}$. On the other hand, a high concentration of the precipitant agent induces the synthesis of the ammonium alunite with lamellar morphology (BAS250 and BAS350) and a particle size of $1 \mu \mathrm{m}$ approximately. This morphology concurs with the XRD difractograms discussed before (Fig. 2). Additionally the morphology observed is in good agreement with the soft TG/DTG curves corresponding with the amorphous material BAS130 and BAS170 (Fig. 3), in comparison with the more defined thermal decomposition of the crystalline structure of the ammonium alunite. Finally, in the spectrums shown in figure $4 \mathrm{a}$ (BAS250 and BAS350) for the ammonium alunite more narrow bands are observed, attributable to the crystalline structure of the final material.

\section{Conclusion}

Ammonium alunite and basic aluminum sulfate can be synthesized by homogeneous precipitation varying the ammonium bisulfite used as a precipitant agent. So, high concentration of the precipitant agent in homogeneous precipitation promotes the formation of ammonium alunite with crystalline structure and lamellar morphology. The ammonium alunite has less $\mathrm{Al}_{2} \mathrm{O}_{3}(28 \%)$ due to the high structural concentration of water and ammonium in comparison with the BAS (48\%). It has a higher amount of sulfate ions and the structural ammonium ion in the BAS is absent. Ammonium bisulfite as a precipitant agent is a new material that can be used to synthesize BAS or ammonium alunite varying the concentration in homogeneous precipitation.

\section{References}

[1] I.N Bhattacharya, P.K. Gochhayat, P.S. Mukherjee, S. Paul, P.K. Mitra,"Thermal decomposition of precipitated low bulk density basic aluminium sulfate", Materials Chemistry and Physics, vol. 88, pp. 32-40, (2004).

[2] E. Kato, K. Daimon, M. Nanbu, "Decomposition of two aluminiumsulphates and characterization of the resultant aluminas", J. Am. Ceram. Soc, vol. 64, pp. 436-443, (1981).

[3] B.C. Cornilsen, J.S. Reed, "Homogeneous Precipitation of Basic Aluminum Salts as Precursors for Alumina", Ceramic Bulletin, vol. 58, pp. 1199(1979).

[4] T. Sugimoto, H. Itoh, H. Miyake,"Formation of monodisperse microcrystal of basic aluminum sulfate by the Gel-Sol method", Journal of Colloid and Interface Science, vol. 188, pp. 101-114,(1997).

[5] R.E. Simpson II, C.Habeger, A. Rabinovic, J.H. Adair, "Enzyme catalyzed inorganic precipitation of aluminium basic sulfate", Journal of the American Ceramic Society, vol. 81, pp. 1377-1379,(1998).

[6] H. Unuma, S. Kato, T. Ota, M. Takahashi, "Homogeneous precipitation of alumina precursors via enzymatic decomposition of urea", Advanced Powder Technol, Vol. (9): pp. 181-190,(1998).

[7] H.H. Willard, N.K. Tang, "A study of the precipitation of Aluminum Basic Sulfate by Urea", J. Am. Chem. Soc, vol. 59, pp. 1190-1196,(1937).

[8] N.G. Apte, E. Kiran, J.V. Chernosky, "Thermal decomposition of aluminium-bearing compounds", Journal of Thermal Analysis, vol. 34, pp. 975-981,(1988).

[9] D. Mishra, S. Anand, R.K. Panda, R.P. Das, "Statistical optimization of conditions for the hydrothermal precipitation of boehmite", Hydrometallurgy, vol. 58, pp. 169-174,(2000). 
[10] J. Lukáč, S. Bakardjieva, V. Štengl, L. Szatmáry, "Hydrous aluminum-oxides prepared by omogeneous precipitation from aluminum (III) sulphate with urea", Ceramics-Silikáty, vol. 50, pp. 22-26,(2006).

[11] S. Sugita, C. Contreras, H. Juárez, A. Aguilera, J. Serrato, "Homogeneous Precipitation and Phase Transformation of Mullite Ceramic Precursor", International Journal of Inorganic Materials, vol. 3, pp. 625-632,(2001).

[12] A. Zamorategui, S. Sugita, R. Zarraga, S. Tanaka S, K. Uematsu, "Evaluation of dispersability of gamma alumina prepared by homogeneous precipitation", Journal of the Ceramic Society of Japan, vol. 120, pp. 290-294,(2012).

[13] R.L. Frost, R.A. Wills, M.L. Weier, W. Martens, J.T. Kloprogge, "A Raman spectroscopic study of alunites", Journal of Molecular Structure, vol. 785, pp. 123-132,(2006).

[14] P. Bayliss, U. Kolitsch, E.H. Nicke, A. Pring, "Alunitesupergroup: recommended nomenclature", Mineralogical Magazine, vol. 74, pp. 919-927,(2010).

[15] B.K. Park, J.M. Jeong,"Effect of the $\mathrm{H}_{2} \mathrm{O} / \mathrm{Al}_{2}\left(\mathrm{SO}_{4}\right)_{3}$ ratio on physical properties in the synthesis of porous $\mathrm{AlO}(\mathrm{OH})$ nano gel by homogeneous precipitation", Journal of Ceramic Processing Research, vol. 9, pp. 204-208,(2008).

[16] A. Zamorategui, J.A. Soto, S. Sugita, "The effect of drying methods on the textural properties of the pseudoboehmite synthesized by homogeneous precipitation", Advances and Applications in Mechanical Engineering and Technology, vol. 4, pp. 1-16,(2012).

[17] J. J. Becerril, I.G. Sosa, I.A. Rivero, "Synthesis of basic aluminum sulfate assisted by microwave heating", Ceramics International, vol. 37, pp. 3627-3630,(2011).
[18] B. Pacewska, J. Pysiak, "Thermal decomposition of basic aluminium-ammonium sulfate (baas) in hydrogen atmosphere", Journal of Thermal Analysis, vol. 37, pp. 16651672,(1991).

[19] R.L. Frost, L. WainDaria, R.A. Wills, A. Musemeci, W. Martens, "A thermogravimetric study of the alunites of sodium, potassium and ammonium", ThermochimicaActa,vol. 443, pp. 56-61,(2006).

[20] S.P. Altaner, J.J. Fitzpatrick, M.D. Krohn, P.M. Brethke, D.O. Hayba, J.A. Goss, Z.A. Brown, "Ammonium in alunites", American Mineralogist, vol. 73, pp. 145-152,(1988).

[21] P.J. Murphy, A.M.L. Smith, K.A. Hudson-Edwards, W.E. Dubbin, K. Wright, "Raman and IR spectroscopic studies of alunite-supergroup compounds containing $\mathrm{Al}, \mathrm{Cr}^{3+}, \mathrm{Fe}^{3+}$ and $\mathrm{V}^{3+}$ at the $b$ site", The Canadian Mineralogist, vol. 47, pp. 663-681,(2009).

[22] N.Y. Mostafa, A.A. Shaltout, H. Omar, S.A Abo-El-Enein, "Hydrothermal synthesis and characterization of aluminium and sulfate substituted $1.1 \mathrm{~nm}$ tobermorites", Journal of Alloysand Compounds, vol. 467, pp. 332-337, (2009).

[23] J.T. Kloprogge, H. Ruan, R.L. Frost, "Near-infrared spectroscopic study of basic aluminum sulfate and nitrate", Journal of Materials Science, vol. 36, pp. 603-607,(2001).

[24] K.M. Parida, A.C. Pradhan, J. Das, N.Sahu, "Synthesis and characterization of nano-sized porous gamma-alumina by control precipitation method", Materials Chemistry and Physics, vol. 113, pp. 244-248,(2009). 